\title{
EFFECT OF MERCURY AND Gpi-2 GENOTYPE ON STANDARD METABOLIC RATE OF EASTERN MOSQUITOFISH (GAMBUSIA HOLBROOKI)
}

\author{
Christopher Paul Tatara, $* \dagger$ Michael C. Newman, $\$$ and Margaret Mulvey $\neq$ \\ $\dagger$ National Marine Fisheries Service, Southwest Region, 777 Sonoma Avenue, Suite 325, Santa Rosa, California 95404, USA \\ $\ddagger$ The College of William and Mary, Virginia Institute of Marine Science, School of Marine Science, Gloucester Point, \\ Virginia 23062-1346, USA
}

(Received 27 January 2000; Accepted 2 August 2000)

\begin{abstract}
Previous studies demonstrated differential mortality among mosquitofish of different Gpi-2 genotypes during acute mercury and arsenate exposures. Mercury-exposed mosquitofish also had Gpi-2 genotype-specific differences in glycolytic and Krebs cycle metabolite pools. The mortality and metabolite data suggested that mosquitofish bearing specific Gpi-2 genotypes might differ in metabolic efficiency, with less efficient Gpi-2 genotypes having higher standard metabolic rates (SMRs) and shorter times to death during acute mercury exposure. Effect of Gpi-2 genotype on SMR was assessed with a factorial arrangement of six Gpi-2 genotypes and two exposure sequences (Control - Control; Control - $100 \mu \mathrm{g} / \mathrm{L} \mathrm{Hg}$ ). The SMRs were estimated by measuring oxygen consumption using an indirect, closed-circuit, computer-controlled respirometer. A 48-h exposure to $100 \mu \mathrm{g} / \mathrm{L}$ of mercury resulted in a $16.7 \%$ elevation of SMR above control levels $(p=0.001)$. The Gpi-2 genotype and the number of heterozygous loci per individual had no significant effect on SMR in mercury-exposed mosquitofish. The experimental results do not support the hypothesis that Gpi-2 genotype-specific differences in glycolytic and Krebs cycle metabolite pools and mortality in mosquitofish exposed to mercury are associated with differences in SMR.
\end{abstract}

Keywords_Gambusia holbrooki Standard metabolic rate Genetics Mercury

\section{INTRODUCTION}

Allozymes have been used as markers for the effects of pollutants on the genetic structure of natural and experimental populations [1-8]. Allozyme genotypes have also proved useful in predicting individual differences in susceptibility to toxicants in laboratory exposures [3,9-14]. Although allozyme studies of exposed populations may be conducted without considering the mechanisms underlying the observed effects, understanding the mechanisms would greatly increase the value of allozyme studies.

Correlation between allozyme genotype frequencies and contaminant exposure in natural and experimental populations and differential susceptibility of specific allozyme genotypes during laboratory exposures to toxicants have provided evidence that variation in allozymes might be useful for detecting the effects of toxicants on natural populations [14-16]. The number of experiments investigating changes in allozyme frequencies in exposed populations and differential sensitivities of allozyme genotypes to toxicants continues to grow, but studies investigating mechanisms underlying the correlation between allozyme genotype and effects of toxicants are relatively uncommon. Newman and Jagoe [17] noted that one of the major problems associated with allozyme studies is that the mechanism of genotype effect is frequently undefined and is considered only speculatively.

Allozymes, allelic forms of an enzyme, are the protein products of DNA sequences. Most allozyme studies involve enzymes that catalyze essential biochemical reactions within the cell-carbohydrate metabolism and adenosine triphosphate

* To whom correspondence may be addressed (chris.p.tatara@NOAA.gov).

Research was performed at the University of Georgia, Aiken, South Carolina, USA.
(ATP) production. The functional nature of allozymes and the variability in stability and kinetic properties between allozymes might provide clues to the physiological mechanisms underlying differential response of allozyme genotypes to toxicants.

This study investigates the relationship between the standard metabolic rate (SMR) during acute mercury exposure and the glucosephosphate isomerase-2 (GPI-2, E.C. 3.5.1.9) (Gpi2) genotype of eastern mosquitofish. Several previous experiments found that mosquitofish, from the Risher Pond population (Barnwell County, SC, USA), exposed acutely to mercury and arsenate had Gpi-2 genotypes consistently correlated with survival time. Mosquitofish homozygous for the rare Gpi2 allele $\left(G p i-2^{38}\right)$ always had the shortest time to death $[3,12,13]$. The consistency of the response associated with the Gpi-2 locus prompted studies of the biochemical differences between Gpi-2 genotypes. Shifts in glycolysis and Krebs cycle metabolites $[18,19]$ indicated that during acute mercury exposure, mosquitofish with the sensitive Gpi-2 genotype ( $G p i-$ $2^{38 / 38}$ ) have enhanced glycolytic activity in contrast to other Gpi-2 genotypes. Glycolysis is the catabolic conversion of glucose to pyruvate with the production of ATP. The rate of glycolysis is limited by how quickly GPI converts glucose-6phosphate to fructose-6-phosphate. A large percentage of the baseline oxygen organisms consume (SMR) is devoted to ATP production. It is therefore reasonable to predict that mosquitofish of different Gpi-2 genotypes, which have shown enhanced glycolytic activity, might exhibit elevated SMR. Additionally, subsequent in vitro studies failed to support the hypothesis that direct mercury inhibition of the GPI-2 allozyme was responsible for the greater sensitivity of the Gpi$2^{38 / 38}$ genotype [20].

We hypothesized that the effect on survival associated with 
the Gpi-2 locus might be associated with inefficient uses of energy substrates by the Gpi-2 $2^{38 / 38}$ genotype during acute toxicant stress. Therefore, we tested whether mosquitofish with different Gpi-2 genotypes would exhibit differences in SMR in response to acute mercury exposure. The effect of Gpi-2 genotype on SMR during mercury exposure was measured as oxygen consumption. The experimental design focused primarily on changes in SMR associated with the Gpi-2 locus; however, the influence of multilocus heterozygosity on SMR was also investigated.

\section{MATERIALS AND METHODS}

\section{Fish populations, culture, and breeding}

The breeding stock was obtained from the Risher Pond (Barnwell County, SC, USA) population, which was used in previous studies of the effects of toxicants on allozyme genotypes [2-4,12,13,18-20]. Because some of the Gpi-2 genotypes occur at low frequencies in the Risher Pond population, mosquitofish were bred in the laboratory to obtain all six Gpi-2 genotypes. The breeding yielded enough mosquitofish to conduct an experiment with statistical power, greatly reduced the number of fish to genotype at the Gpi-2 locus, and produced fish with approximately the same mass regardless of Gpi-2 genotype. Fish were transported to the laboratory, and maintained in 530- and 720-L artificial streams (Living Stream, Toledo, $\mathrm{OH}, \mathrm{USA})$ at $20^{\circ} \mathrm{C}$. The breeding stock was anesthetized using $85 \mathrm{mg} / \mathrm{L}$ of tricaine methanesulfonate (Sigma Chemical, St. Louis, MO, USA), and a portion of the caudal fin was clipped for electrophoretic determination of Gpi-2 genotype. Male and female mosquitofish heterozygous and homozygous for the $G p i-2^{38}$ allele were placed in outdoor cattle tanks filled with well water during the summer months to provide warm water temperatures and long photoperiods, which promoted reproduction. Fish were fed Tetramin flake food (Tetra Sales, Blacksburg, VA, USA) daily. The breeding stock also foraged on the natural growth of algae and invertebrates present in the cattle tanks. Gravid females were netted from the cattle tanks, brought into laboratory aquaria filled with soft reconstituted water [21] at $25^{\circ} \mathrm{C}$, and placed in brood chambers to prevent cannibalization of the young. Larval fish were fed live brine shrimp nauplii and Tetramin ${ }^{\mathbb{T i N}}$ larval fish food for live-bearers (Tetra Sales) until they were large enough to eat regular flake food and adult brine shrimp. Juvenile mosquitofish were transferred to artificial streams and reared at $20^{\circ} \mathrm{C}$ until they matured. Determination of the Gpi-2 genotype for mature fish was accomplished using the procedures previously described for the breeding stock. Fish were then sorted by $G$ pi- 2 genotype and held at $20^{\circ} \mathrm{C}$ in the artificial streams until measurement of SMR.

\section{Genotype}

In addition to GPI-2, the following enzymes, which have been routinely assayed in our studies of Risher Pond mosquitofish, were included: fumarate hydratase (FUM, E.C. 4.2.1.2), mannosephosphate isomerase (MPI, E.C. 3.5.1.8), adenosine deaminase (ADA, E.C. 3.5.4.4), malate dehydrogenase-1 (MDH-1, E.C. 1.1.1.37), and isocitrate dehydrogenase-1,2 (ICD-1 \& 2, E.C. 1.1.1.42). Horizontal starch gel electrophoretic methods were those described previously $[3,12,13]$.

\section{Mercury exposure}

All mercury exposures were conducted in reconstituted soft water [21]. Both the control and the mercury-treated groups of mosquitofish were starved for $24 \mathrm{~h}$ prior to exposure. Mosquitofish were exposed nominally to $100 \mu \mathrm{g} / \mathrm{L}$ of $\mathrm{Hg}$ (as $\mathrm{HgCl}_{2}$ ) for $24 \mathrm{~h}$ prior to respirometry procedures in a $7-\mathrm{L}$ aerated aquarium maintained at $20^{\circ} \mathrm{C}$. Mosquitofish were placed in chambers within the $7-\mathrm{L}$ aquarium during the mercury exposure in order to identify individuals by Gpi-2 genotype. This experimental design allowed all genotypes to be exposed during each respirometry session and minimized any differences in metabolic rates attributed to measurement session. The mercury exposure solution was renewed at hour 24 of the exposure, prior to placing fish in the respirometer for an additional $24 \mathrm{~h}$ of exposure during oxygen consumption measurement.

\section{Experimental design}

Effect of Gpi-2 genotype on SMR was assessed with a factorial arrangement of all six Gpi-2 genotypes and two exposure sequences. The control sequence was defined as two 24-h respirometry sessions conducted in reconstituted dilution water separated by at least one week. The mercury exposure sequence consisted of a 24-h respirometry session in reconstituted dilution water, followed at least one week later with exposure to $100 \mu \mathrm{g} / \mathrm{L} \mathrm{Hg}$ for $24 \mathrm{~h}$, immediately followed by a $24-\mathrm{h}$ respirometry session conducted in $100 \mu \mathrm{g} / \mathrm{L}$ of $\mathrm{Hg}$. Ten fish of each genotype were assigned to the control sequence, and 10 fish of each genotype were assigned to the mercury exposure sequence. Wet mass of each mosquitofish was determined after the second respirometry session in each exposure sequence in order to minimize the effects of handling stress on the fish. The response variable $(\Delta \mathrm{SMR})$ was calculated as the difference in SMR between the first and second respirometry sessions in each exposure sequence.

\section{Water quality parameters and mercury analysis}

Temperature, specific conductance, dissolved oxygen, and $\mathrm{pH}$ were monitored at $0,24,25$, and $48 \mathrm{~h}$ during the exposure period using a Microsonde water quality multiprobe (Hydrolab, Austin, TX, USA). Water samples for mercury analysis were taken at $0,24,25$, and $48 \mathrm{~h}$; acidified with trace metalgrade nitric acid; and stored at $4{ }^{\circ} \mathrm{C}$ until analysis. Total mercury was determined by cold vapor atomic fluorescence spectroscopy using a Model 2 analyzer (Brooks Rand, Seattle, WA, USA).

\section{Respirometry techniques}

Standard metabolic rates were obtained using a closed-circuit, computer-controlled indirect respirometer (Micro-oxymax, Columbus Instruments, Columbus, OH, USA). Each fish was placed in a 50-ml Erlenmeyer ${ }^{\circledR}$ flask (Bellco Glass, Vineland, NJ, USA) containing $35 \mathrm{ml}$ of reconstituted soft water or $100 \mu \mathrm{g} / \mathrm{L}$ mercury exposure solution. During each respirometry session, metabolic rates could be obtained for 18 fish, one blank, and one reference standard, an 8.4-V zinc air medical battery (Duracell, Bethel, CT, USA), which consumed oxygen at a known rate. Respirometry chambers were placed in a dark environmental chamber at $20 \pm 1^{\circ} \mathrm{C}$. Oxygen consumption of each fish was determined at 2.1-h intervals for $24 \mathrm{~h}$. After the second respirometry session of an exposure sequence, each fish was weighed to the nearest milligram and frozen at $-70^{\circ} \mathrm{C}$ until allozyme analysis was performed. 
Table 1. Average standard metabolic rate (SMR), mass-corrected SMR, and mass of mosquitofish by genotype and exposure sequence

\begin{tabular}{|c|c|c|c|c|c|c|c|c|c|c|c|c|c|c|}
\hline \multirow[b]{3}{*}{ Variable } & \multicolumn{14}{|c|}{ Gpi-2 genotype } \\
\hline & \multicolumn{2}{|c|}{$100 / 100$} & \multicolumn{2}{|c|}{$100 / 66$} & \multicolumn{2}{|c|}{$100 / 38$} & \multicolumn{2}{|r|}{$66 / 66$} & \multicolumn{2}{|c|}{$66 / 38$} & \multicolumn{2}{|c|}{$38 / 38$} & \multicolumn{2}{|c|}{ All fish } \\
\hline & $n$ & $\begin{array}{c}\bar{X} \\
(\mathrm{SD})^{\mathrm{a}}\end{array}$ & $n$ & $\begin{array}{c}\bar{X} \\
(\mathrm{SD})\end{array}$ & $n$ & $\begin{array}{c}\bar{X} \\
(\mathrm{SD})\end{array}$ & $n$ & $\begin{array}{c}\bar{X} \\
(\mathrm{SD})\end{array}$ & $n$ & $\begin{array}{c}\bar{X} \\
(\mathrm{SD})^{\mathrm{a}}\end{array}$ & $n$ & $\begin{array}{c}\bar{X} \\
(\mathrm{SD})\end{array}$ & $n$ & $\begin{array}{c}\bar{X} \\
(\mathrm{SD})\end{array}$ \\
\hline \multicolumn{15}{|l|}{ Control sequence } \\
\hline $\mathrm{SMR}(\mathrm{ml} \mathrm{O} / \mathrm{h})$ & 10 & $\begin{array}{c}0.034 \\
(0.013)\end{array}$ & 11 & $\begin{array}{c}0.028 \\
(0.009)\end{array}$ & 10 & $\begin{array}{c}0.031 \\
(0.006)\end{array}$ & 8 & $\begin{array}{c}0.027 \\
(0.007)\end{array}$ & 10 & $\begin{array}{c}0.032 \\
(0.011)\end{array}$ & 11 & $\begin{array}{c}0.031 \\
(0.011)\end{array}$ & 60 & $\begin{array}{c}0.030 \\
(0.010)\end{array}$ \\
\hline $\begin{array}{l}\text { Mass-corrected SMR } \\
(\mathrm{ml} \mathrm{O} / \mathrm{h} / \mathrm{g})\end{array}$ & 10 & $\begin{array}{c}0.154 \\
(0.030)\end{array}$ & 11 & $\begin{array}{c}0.161 \\
(0.028)\end{array}$ & 10 & $\begin{array}{c}0.162 \\
(0.041)\end{array}$ & 8 & $\begin{array}{l}0.157 \\
(0.015)\end{array}$ & 10 & $\begin{array}{c}0.181 \\
(0.054)\end{array}$ & 11 & $\begin{array}{c}0.147 \\
(0.022)\end{array}$ & 60 & $\begin{array}{l}0.160 \\
(0.035)\end{array}$ \\
\hline Mass $(\mathrm{g})^{\mathrm{b}}$ & 10 & $\begin{array}{c}0.219 \\
(0.056)\end{array}$ & 11 & $\begin{array}{c}0.174 \\
(0.050)\end{array}$ & 10 & $\begin{array}{c}0.199 \\
(0.054)\end{array}$ & 8 & $\begin{array}{c}0.175 \\
(0.058)\end{array}$ & 10 & $\begin{array}{c}0.180 \\
(0.051)\end{array}$ & 11 & $\begin{array}{c}0.213 \\
(0.084)\end{array}$ & 60 & $\begin{array}{c}0.194 \\
(0.061)\end{array}$ \\
\hline \multicolumn{15}{|l|}{ Mercury sequence } \\
\hline $\operatorname{SMR}\left(\mathrm{ml} \mathrm{O}_{2} / \mathrm{h}\right)$ & 10 & $\begin{array}{c}0.035 \\
(0.011)\end{array}$ & 11 & $\begin{array}{c}0.031 \\
(0.007)\end{array}$ & 10 & $\begin{array}{c}0.037 \\
(0.008)\end{array}$ & 9 & $\begin{array}{c}0.038 \\
(0.012)\end{array}$ & 10 & $\begin{array}{c}0.035 \\
(0.013)\end{array}$ & 10 & $\begin{array}{c}0.033 \\
(0.006)\end{array}$ & 60 & $\begin{array}{c}0.035 \\
(0.010)\end{array}$ \\
\hline $\begin{array}{l}\text { Mass-corrected SMR } \\
\left(\mathrm{ml} \mathrm{O} \mathrm{O}_{2} / \mathrm{h} / \mathrm{g}\right)\end{array}$ & 10 & $\begin{array}{c}0.176 \\
(0.030)\end{array}$ & 11 & $\begin{array}{c}0.176 \\
(0.030)\end{array}$ & 10 & $\begin{array}{c}0.183 \\
(0.026)\end{array}$ & 9 & $\begin{array}{c}0.191 \\
(0.045)\end{array}$ & 10 & $\begin{array}{c}0.193 \\
(0.052)\end{array}$ & 10 & $\begin{array}{c}0.180 \\
(0.035)\end{array}$ & 60 & $\begin{array}{c}0.183 \\
(0.036)\end{array}$ \\
\hline Mass $(\mathrm{g})^{\mathrm{b}}$ & 10 & $\begin{array}{c}0.203 \\
(0.076)\end{array}$ & 11 & $\begin{array}{c}0.184 \\
(0.058)\end{array}$ & 10 & $\begin{array}{c}0.209 \\
(0.058)\end{array}$ & 9 & $\begin{array}{c}0.214 \\
(0.089)\end{array}$ & 10 & $\begin{array}{c}0.199 \\
(0.107)\end{array}$ & 10 & $\begin{array}{c}0.188 \\
(0.039)\end{array}$ & 60 & $\begin{array}{c}0.199 \\
(0.072)\end{array}$ \\
\hline
\end{tabular}

${ }^{a} \mathrm{SD}=$ standard deviation.

b There were no significant differences in mass among glucosephosphate isomerase-2 (Gpi-2) genotypes $(p=0.70)$ or between exposure sequences $(p=0.69)$.

\section{Data analysis}

Because SMR should be measured when fish are expending no energy for activity [22], SMR for each individual was calculated by taking the mean of the lowest $50 \%$ of all oxygen consumption measurements. Deletion of the highest $50 \%$ of all measurements reduced measurements that may have occurred during periods of activity [23]. Differences in mass among fish of different Gpi-2 genotypes and among fish in different exposure sequences were determined using procedure GLM of the Statistical Analysis System [24]. The results of this analysis were used to decide whether mass should be used as a covariate in the analysis of the SMR data. Analysis of variance for a factorial experiment was used to determine the effects of mercury exposure, Gpi-2 genotype, and heterozygosity on $\triangle \mathrm{SMR}$ with procedure GLM of the Statistical Analysis System [24].

\section{RESULTS}

Analysis of variance indicated no significant differences in mass among $G p i-2$ genotypes $(p=0.70)$ or between exposure sequences $(p=0.69)$ (Table 1$)$. Therefore, mass was not used as a covariate in the analysis of the SMR data.

Water quality remained consistent among the seven acute mercury exposures as well as throughout the 48-h duration of each exposure (Table 2). Measured mercury concentrations were lower than the target concentration of $100 \mu \mathrm{g} / \mathrm{L}$. Mercury concentration decreased between each 24-h renewal (Table 2).

Average SMRs and mass-corrected SMRs by Gpi-2 genotype and treatment are reported in Table 1. Acute exposure to mercury resulted in an increase in SMR. The mean SMR of the mercury-exposed fish $\left(0.035 \pm 0.010 \mathrm{ml} \mathrm{O}_{2} / \mathrm{h}\right)$ was $16.7 \%$ higher than the mean SMR of the control fish $(0.030$ $\pm 0.010 \mathrm{ml} \mathrm{O}_{2} / \mathrm{h}$ ). Analysis of variance indicated a significant

Table 2. Water quality parameters and mercury concentrations in exposure tanks averaged across seven exposure sessions ${ }^{\mathrm{a}}$

\begin{tabular}{lccccc}
\hline & \multicolumn{5}{c}{ Treatment } \\
\cline { 2 - 6 } Parameter & $\begin{array}{c}\text { Control } \\
\text { hour } 0\end{array}$ & $\begin{array}{c}\text { Mercury } \\
\text { hour } 0\end{array}$ & $\begin{array}{c}\text { Mercury } \\
\text { hour } 24\end{array}$ & $\begin{array}{c}\text { Mercury } \\
\text { hour 25 }\end{array}$ & $\begin{array}{c}\text { Mercury } \\
\text { hour 48 }\end{array}$ \\
\hline Temperature $\left({ }^{\circ} \mathrm{C}\right)$ & 20.33 & 19.41 & 20.53 & 20.36 & $\mathrm{c}$ \\
& $(0.65)$ & $(0.26)$ & $(0.51)$ & $(0.59)$ & $\mathrm{c}$ \\
Dissolved $\mathrm{O}_{2}(\%$ saturation) & 98.1 & 96.2 & 97.7 & 98.4 & $\mathrm{c}$ \\
Specific conductance $(\mu \mathrm{S} / \mathrm{cm})$ & $(1.3)$ & $(2.4)$ & $(2.7)$ & $(1.3)$ & $\mathrm{c}$ \\
pH & 167 & 165 & 171 & 167 & $\mathrm{c}$ \\
& $(2)$ & $(2)$ & $(2)$ & $(2)$ & $\mathrm{c}$ \\
Mercury $(\mu \mathrm{g} / \mathrm{L}$ or $\mathrm{ppb})$ & 7.85 & 7.49 & 7.83 & 7.45 & $\mathrm{c}$ \\
& $(0.60)$ & $(0.08)$ & $(0.03)$ & $(0.03)$ & $\mathrm{c}$ \\
& 0.15 & 62.00 & 16.20 & 74.49 & 5.26 \\
& $(0.03)$ & $(13.22)$ & $(4.33)$ & $(16.15)$ & $(2.15)$ \\
\hline
\end{tabular}

${ }^{\text {a }} n=7$ for all observations; mean (standard deviation)

b The 100- $\mu \mathrm{g} / \mathrm{L}$ mercury exposure solution was renewed between hours 24 and 25 .

c The volume of exposure solution available at hour 48 was insufficient to measure these water quality parameters. 
Table 3. Results of analysis of variance comparing the effects of glucosephosphate isomerase-2 (Gpi2) genotype and number of heterozygous loci per individual on standard metabolic rate in mosquitofish exposed acutely to mercury

\begin{tabular}{lrccrr}
\hline Source & $d f$ & SS & MS & \multicolumn{1}{c}{$F$} & \multicolumn{1}{c}{$p$} \\
\hline Exposure sequence & 1 & 0.000438 & 0.000438 & 10.81 & 0.001 \\
Gpi-2 genotype & 5 & 0.000026 & 0.000005 & 0.13 & 0.985 \\
Exposure $\times$ genotype & 5 & 0.000096 & 0.000019 & 0.47 & 0.796 \\
Error & 108 & 0.004373 & 0.000040 & & \\
Total & 119 & 0.004932 & & & \\
Exposure sequence & 1 & 0.000467 & 0.000467 & 14.59 & $<0.001$ \\
Heterozygosity & 5 & 0.000487 & 0.000097 & 3.04 & 0.013 \\
Exposure $\times$ heterozygosity & 4 & 0.000476 & 0.000119 & 3.71 & 0.007 \\
Error & 108 & 0.003459 & 0.000032 & & \\
Total & 118 & 0.004889 & & & \\
\hline
\end{tabular}

increase in $\Delta$ SMR $(p=0.001)$ in mosquitofish acutely exposed to mercury. However, no statistically significant Gpi-2 genotype $\times$ mercury exposure interaction was observed (Table 3 ). The number of heterozygous loci per individual appeared to have a significant effect on $\triangle \mathrm{SMR}(\mathrm{p}=0.01)$ as well as a significant interaction between heterozygosity and mercury exposure $(p=0.007)$. Both the effect of heterozygosity and the heterozygosity $\times$ mercury exposure interaction were highly influenced by the observations for control fish heterozygous at zero and four loci, which were represented by small sample sizes (one individual). Exclusion of control fish heterozygous at zero and four loci from the analysis eliminated the heterozygosity effect as well as the interaction with mercury exposure. Mercury exposure was the only significant effect remaining $(p<0.001)$.

\section{DISCUSSION}

The results of previous toxicological, biochemical, and physiological studies suggested that mosquitofish with different Gpi-2 genotypes might have different SMRs during mercury exposure $[3,12,13,18-20]$. Mulvey et al. [2] found that Gpi-2 genotype affected the probability of a mercury-exposed female mosquitofish being gravid as well as the number of late-stage embryos carried. Fitness differences among Gpi-2 genotypes in survival and reproduction during acute and chronic mercury stress, respectively, could reflect differences in metabolic rates during mercury exposure.

The SMRs measured in this study were similar to values by other researchers. Cech et al. [25] obtained resting routine metabolic rates of $0.042 \pm 0.007 \mathrm{ml} \mathrm{O}_{2} / \mathrm{h}$ in the closely related western mosquitofish (Gambusia affinis) under conditions similar to the control sequence in this study $\left(20^{\circ} \mathrm{C}\right.$, normoxia, fish of similar mass). Resting routine metabolic rate includes measurements made during periods of limited activity. For this reason, it is usually slightly higher than the SMR [26]. Our estimate of SMR was $0.030 \pm 0.01 \mathrm{ml} \mathrm{O}_{2} / \mathrm{h}$ for the control fish in this study.

Significant effects of multilocus heterozygosity were observed for SMR and for heterozygosity $\times$ exposure interaction. A significant positive correlation between multilocus heterozygosity and metabolic rate (measured as $\mathrm{O}_{2}$ consumption) has been reported for several fish and molluscan species in a review by Mitton [27]. In the present study, the relationship between SMR and heterozygosity must be viewed cautiously because of the small sample sizes in some heterozygosity categories. The present study was designed primarily to test the effect of Gpi-2 genotype on SMR during mercury exposure, and ad- ditional variables were examined secondarily. Additional study would be needed to confirm or reject the relationship between multilocus heterozygosity and SMR.

Given the consistency of the response associated with Gpi2 genotype in previous studies, it is important to consider why Gpi-2 genotype did not influence SMR during acute mercury exposure. The SMR can be more thoroughly defined as the energy needed to complete all the anabolic and catabolic activities within the organism, with the majority devoted to aerobic ATP production [22]. Glucosephosphate isomerase (GPI) is an enzyme central to carbohydrate metabolism and is situated at the branch-point between glycogen synthesis and glycolysis. Glucosephosphate isomerase interconverts glucose-6phosphate and fructose-6-phosphate, the first step in glycolysis leading to ATP production [28]. Although GPI plays a central role in carbohydrate metabolism and glycolysis, it is only one of many enzymes mediating the cellular biochemical reactions that sum to SMR. Differences in glycolytic and Krebs cycle metabolites among Gpi-2 genotypes may occur during acute mercury exposure $[18,19]$; however, the effect may not be large enough to be detected as a significant increase in oxygen consumption.

Several additional reasons might explain our failure to detect a relationship between Gpi-2 genotype and SMR in mosquitofish exposed to mercury. Because the effect of Gpi-2 genotype on SMR might be small, a larger experiment might be necessary to detect the effect. Differential survival among Gpi-2 genotypes during mercury exposure may not be manifested as differences in SMR. A measurement of metabolic rate that includes energy allocated to activity might more accurately match the behavior of the mosquitofish during previous exposures and detect effects of the Gpi-2 locus. It is also possible that the exposed fish compensated for the increase in SMR by switching to anaerobic metabolic pathways. The respirometry methods used in this study were unable to measure anaerobic metabolism. Finally, an unknown mechanism associated with a gene linked to Gpi-2 might be responsible for effects previously associated with Gpi-2. Additional research is required to determine what role Gpi-2 (or linked loci) plays in determining susceptibility to acute toxicant stress $[3,12,13,29,30]$ and adaptation in populations chronically exposed to toxicants $[2,4]$.

Acknowledgement-Research and manuscript preparation was supported by Financial Assistance Award DE-FC09-96SR18546 from the U.S. Department of Energy to the University of Georgia Research Foundation. The authors would like to thank W. Hopkins, J. Roe, M. 
Komoroski, G. Plague, P. Johns, A. Kelsey, J. Congdon, M. Smith, C. Jagoe, and P. Dixon.

\section{REFERENCES}

1. Gillespie RB, Guttman SI. 1989. Effects of contaminants on the frequencies of allozymes in populations of the central stoneroller. Environ Toxicol Chem 8:309-317.

2. Mulvey M, Newman MC, Chazal A, Keklak MM, Heagler MG, Hales LS. 1995. Genetic and demographic responses of mosquitofish (Gambusia holbrooki Girard 1859) populations stressed by mercury. Environ Toxicol Chem 14:1411-1418.

3. Heagler MG, Newman MC, Mulvey M, Dixon PM. 1993. Allozyme genotype in mosquitofish, Gambusia holbrooki, during mercury exposure: Temporal stability, concentration effects and field verification. Environ Toxicol Chem 12:385-395.

4. Tatara CP, Mulvey M, Newman MC. 1999. Genetic and demographic responses of mosquitofish (Gambusia holbrooki) populations exposed to mercury for multiple generations. Environ Toxicol Chem 18:2840-2845.

5. Roark S, Brown K. 1996. Effects of metal contamination from mine tailings on allozyme distributions of populations of great plains fishes. Environ Toxicol Chem 15:921-927.

6. Sloss BL, Romano MA, Anderson RV. 1998. Pollution-tolerant allele in fingernail clams (Musculium transversum). Arch Environ Contam Toxicol 35:302-308.

7. Nevo E, Ben-Shlomo R, Lavie B. 1984. Mercury selection of allozymes in marine organisms: Prediction and verification in nature. Proc Natl Acad Sci 81:1258-1259.

8. Nevo E, Shimony T, Libni M. 1977. Pollution selection of allozyme polymorphism in barnacles. Experientia 34:1562-1564

9. Schlueter MA, Guttman SI, Oris JT, Bailer AJ. 1995. Survival of copper-exposed juvenile fathead minnows (Pimephales promelas) differs among allozyme genotypes. Environ Toxicol Chem 14:1727-1734.

10. Lavie B, Nevo E. 1988. Multilocus genetic resistance and susceptibility to mercury and cadmium pollution in the marine gastropod, Cerithium scabridum. Aquat Toxicol 13:291-296.

11. Chagnon NL, Guttman SI. 1989. Differential survivorship of allozyme genotypes in mosquitofish populations exposed to copper or cadmium. Environ Toxicol Chem 8:319-326.

12. Diamond SA, Newman MC, Mulvey M, Dixon PM, Martinson D. 1989. Allozyme genotype and time to death of mosquitofish, Gambusia affinis (Baird and Girard) during acute exposure to inorganic mercury. Environ Toxicol Chem 8:613-622.

13. Newman MC, Diamond SA, Mulvey M, Dixon PM. 1989. Allozyme genotype and time to death of mosquitofish, Gambusia affinis (Baird and Girard) during acute toxicant exposure: A comparison of arsenate and inorganic mercury. Aquat Toxicol 15: 141-156.

14. Sullivan KB, Lydy MJ. 1999. Differences in survival functions of mosquitofish (Gambusia affinis) and sand shiner (Notropis ludibundus) genotypes exposed to pesticides. Environ Toxicol Chem 18:906-911.

15. Gillespie RB, Guttman SI. 1999. Chemical-induced changes in the genetic structure of populations: Effects on allozymes. In
Forbes VE, ed, Genetics and Ecotoxicology. Taylor \& Francis, Philadelphia, PA, USA, pp 55-77.

16. Guttman SI. 1994. Population genetic structure and ecotoxicology. Environ Health Perspect 102(Suppl. 12):97-100.

17. Newman MC, Jagoe RH. 1998. Allozymes reflect the populationlevel effect of mercury: Simulations of the mosquitofish (Gambusia holbrooki Girard) GPI-2 response. Ecotoxicology 7:141150 .

18. Kramer VJ, Newman MC, Ultsch GR. 1992. Changes in concentrations of glycolysis and Krebs cycle metabolites in mosquitofish, Gambusia holbrooki, induced by mercuric chloride and starvation. Environ Biol Fishes 34:315-320.

19. Kramer VJ, Newman MC, Mulvey M, Ultsch GR. 1992. Glycolysis and Krebs cycle metabolites in mosquitofish, Gambusia holbrooki, Girard 1859, exposed to mercuric chloride: Allozyme genotype effects. Environ Toxicol Chem 11:357-364.

20. Kramer VJ, Newman MC. 1994. Inhibition of glucosephosphate isomerase allozymes of the mosquitofish, Gambusia holbrooki, by mercury. Environ Toxicol Chem 13:9-14.

21. Weber CI. 1991. Methods for measuring the acute toxicity of effluents and receiving waters to freshwater and marine organisms, 4th ed. EPA-600/4-90-027. U.S. Environmental Protection Agency, Cincinnati, OH.

22. Cech JJ Jr. 1990. Respirometry. In Schreck CB, Moyle PB, eds, Methods for Fish Biology. American Fisheries Society, Bethesda, MD, pp 335-362.

23. Rowe CL, Kinney OM, Nagle RD, Congdon JD. 1998. Elevated maintenance costs in an anuran (Rana catesbeiana) exposed to a mixture of trace elements during the embryonic and early larval periods. Physiol Zool 71:27-35.

24. SAS Institute. 1987. SAS ${ }^{\circledR / S T A T ~ G u i d e ~ f o r ~ P e r s o n a l ~ C o m p u t e r s, ~}$ Ver 6. Cary, NC, USA.

25. Cech JJ Jr, Massingill MJ, Vondracek B, Linden AL. 1985. Respiratory metabolism of mosquitofish, Gambusia affinis: Effects of temperature, dissolved oxygen, and sex difference. Environ Biol Fishes 13:297-307.

26. Fry FEJ. 1971. The effect of environmental factors on the physiology of fish. In Hoar WS, Randall DJ, eds, Fish Physiology, Vol 6. Academic, New York, NY, USA, pp 1-98.

27. Mitton JB. 1993. Theory and data pertinent to the relationship between heterozygosity and fitness. In Thornhill NW, ed, The Natural History of Inbreeding and Outbreeding: Theoretical and Empirical Perspectives. University of Chicago Press, Chicago, IL, USA, pp 17-41.

28. Kempson SA. 1989. Energy and cellular metabolism. In Rhoades R, Pflanzer R, eds, Human Physiology. Saunders, Philadelphia, PA, USA, pp 179-207.

29. Kandl KL, Thompson AJ. 1996. Responses of eastern mosquitofish (Gambusia holbrooki) to acute salinity stress: Do family effects obscure inbreeding and genotype effects? Can J Fish Aquat Sci 53:753-760.

30. Hughes JM, Harrison DA, Arthur JM. 1991. Genetic variation at the Pgi locus in the mosquitofish Gambusia affinis (Poecilidae) and a possible effect on susceptibility to an insecticide. Biol J Linn Soc 44:153-167. 